Indonesian Journal of Global Health Research

Volume 3 Number 1, February 2021, pp. 15 - 28

e-ISSN 2715-1972; p-ISSN 2714-9749

http://jurnal.globalhealthsciencegroup.com/index.php/IJGHR

\title{
CHANGE IN WHITE MALE RATS' WEIGHT AND EPIDIDIMIC HISTOLOGY DUE TO THE PROVISION OF WHITE TURMERIC EXTRACT AND FRACTION
}

\author{
Rinda Lamdayani*, Aryanti \\ STIKES Abdurahman Palembang, Jl. Suka Jaya No.7, Suka Bangun, Kec. Sukarami, Kota Palembang, Sumatera \\ Selatan, Indonesia 30151 \\ *rindalamdayani5@gmail.com
}

\begin{abstract}
The low participation of Men in the family planning program is due to the limited choice of male contraceptives that can be used. This makes experts trying to find a way that is safe for men, one way is to switch plants that can inhibit the spermatogenesis. One of the traditional medicines that has been studied and has anti-fertility effectiveness is the white turmeric plant. This study aimed to determine the effect of extracts and fraction of white turmeric on changes in weight and histology of white male rats (Rattus norvegicus) epididymis. This research was an experimental study using a completely randomized design (CRD). The samples in this study were 25 white male rats that met the inclusion criteria which were divided into 5 groups, each group consisting of 5 rats obtaining a dose of $300 \mathrm{mg} / \mathrm{kgBW} / \mathrm{day}$, treated for 48 days and stopped for surgery on the day 49. After that, the analysis was carried out using One Way Anova test and continued with Duncan's test. The provisions of extracts and fractions of white turmeric can reduce the weight and histological structure of the epididymis of the head, corpus, and cauda.
\end{abstract}

Keywords: extract; fraction; thickness of caput epithelium; thickness of cauda epithelium; thickness of corpus epithelium; weight of epididymis

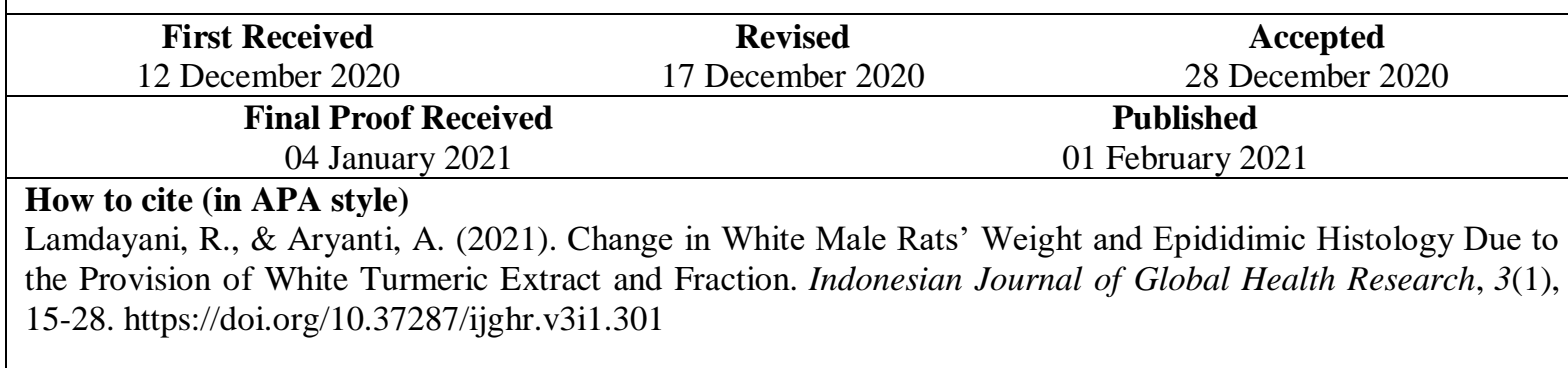

\section{INTRODUCTION}

The participation of men is one of the factors in the success of the Family Planning (KB) program. No matter how good the government program is but without an active role from the community, the program will not achieve the expected results. Increasing men's participation in family planning and reproductive health is one of the important issues in reproductive health. According to Suratun (2008), the reason for the low participation of men in family planning program is due to the limited knowledge of husbands about reproductive health and the paradigm related to a patriarchal culture where the role of men is greater than women. Gender inequality and reproductive health greatly influence the success of the family planning program. Most people still think that contraception is a woman's business.

In terms of gender, the female contraceptive method used was greater than the male contraceptive method. The female method was $93.66 \%$, while the male method was only $6.34 \%$. This shows that men's participation in using contraceptives is still very small compared to women (BKKBN, 2014). The use of modern contraceptive methods for men in Indonesia has not been able to develop as expected. Current male contraceptive methods used are only condoms and vasectomy. One of the concerns of men after having a vasectomy is that they feel the loss of their virility and men are afraid of impotence due to vasectomy and 
there is a misperception and even a negative view that vasectomy is the same as castration, so that men are reluctant to undergo vasectomy (Martinez et al., 2002). This makes experts try to find a way that is safe for men, but will not make them feel that their masculinity removed. One way is to switch to plants which can inhibit spermatogenesis. Spermatogenesis is an active development process from primordial spermatogenic cells to mature spermatozoa. The spermatogenesis process occurs in the seminiferous tubules of the testes. This process under normal circumstances can occur at any time. The quality of spermatozoa can be seen from various factors, including: morphology (sperm abnormalities) and motility (fast motion) while the quantity of spermatozoa can be seen from the number of spermatozoa (Naomi \& Sari, 2016).

Efforts to obtain male contraceptives derived from plants have been widely studied, but the results have not been satisfying. Therefore, the use of plant materials is still a priority to be investigated considering that medicinal substances derived from plants have advantages, including low toxicity, easy access, cheap price, less side effects and considered safe if it continues to be consumed continuously. As for one of the spices that are widely grown in Indonesia and used for traditional medicine, one of them is white turmeric [C. zedoaria (Berg.) Roscoe) (Murwati and Nurrahmat, 2000).

Most of the traditional medicines have the main component from plants of the empon-empon class (family zingiberaceae), especially the genus Curcuma. Turmeric plants (Curcuma domestica), Javanese turmeric (Curcuma xanthorrhiza) and white turmeric [C. zedoaria (Berg.) Roscoe) are ingredients which dominate the composition of most traditional medicines. Therefore as for one of the factors that is expected to be anti-fertility is white turmeric [C. zedoaria (Berg.) Roscoe). Research on white turmeric plant as an alternative to traditional male contraceptives has not been widely studied. White turmeric [C. zedoaria (Berg.) Roscoe] contains volatile oil. The evaporated oil contains more than 20 components such as curzerenone (zedoarin) which is the largest component, flavonoids, sulfur, gum, resin, flour, and a little fat (Ashfahani et al., 2000). Meanwhile, flavonoid compounds that have activity, such as estrogen, are thought to suppress the anterior pituitary function to secrete FSH and LH according to previous research (Delfita, 2014).

Excess flavonoid chemical content can lead to a decrease in epididymal weight due to damage to epididymal cell membranes. Based on the results of previous studies, the continuous administration of white turmeric extract can cause a decrease in the mitotic number of spermatogenic cells.(Biology \& Viability, 2010). In addition, the decrease in spermatogenic cells can also be caused by the presence of cytotoxic substances in the white turmeric, which interfere with the growth and development of cell tissues. As a result of disruption of the growth and development of this tissue, the number of spermatogenic cells decreases because spermatogenic cells are cells that actively divide (Siswanti et al., 2003).

According to some of the research above, it is known that white turmeric [C. zedoaria (Berg.) Roscoe] can cause infertility. The results of these studies need to be continued with research on the compounds contained by White Turmeric [C. zedoaria (Berg.) Roscoe] from the extraction and fractionation processes as a cause of infertility. This research was conducted to determine the effect of the extract and fraction of white turmeric [C. zedoaria (Berg.) Roscoe] on changes in weight and histology of the epididymis of white male rats (Rattus norvegicus). 


\section{METHOD}

The research carried out was experimental research at the Laboratory of the Medical Biology Section of the Faculty of Medicine, the Laboratory of the Faculty of Mathematics and Natural Sciences, UNSRI, and the Laboratory of Anatomical Pathology, Dyatnitalis. The tools used in this study were mouse cages, gloves, surgical scissors, $1 \mathrm{ml}$ syringe, mouse feeder, tray, rat drink bottle, rat feeding bowl, scalpel, tweezers, a tool for extracting rat epididymis, analytical scales (Satorius type H 110) to weigh the epididymis, containers to accommodate the epididymis before making histological preparations, hot plates, cassettes, shadon citadel 2000 tools for tissue processing from infiltration fixation, 3 tools of shadon histocentre for making paraffin blocks, base molds, cooling plate, microtome, tools for cutting paraffin blocks, water bath a tool for selecting the results of sliced tape, glass objects, hot plate, microscope (Olympus CX31), micrometeroculars for histological observation of preparations and microfoto. The work procedures include preparing the provision of experimental animals, grouping the experimental animals, calculating dosages, and preparing test materials. The research design used for grouping and treating the tested animals was a completely randomized design (CRD), which is a design with multiple treatments and arranged randomly for all experimental units using the Post test only technique. The test animals used in this study were white male rats (Rattus norvegicus). A total of 25 rats aged 60 days with a body weight of 210-220 grams obtained from Bandung Ranch.

\section{RESULTS \\ White Turmeric Fraction}

Table 1.

Results of the Fractionation of White Turmeric Extract.

\begin{tabular}{lll}
\hline Solvent & Fraction Weight $(\mathrm{g})$ & Percent weight $(\%)$ \\
\hline N-Hexan & 28.8 & 21.5 \\
\hline Ethyl acetate & 37 & 80.5 \\
\hline Methanol water & 41.8 & Percent weight $(\%)$ \\
\hline
\end{tabular}

Based on the results of the fractionation of the white turmeric extract in table 1 from the water methanol solvent obtained $41.8 \mathrm{~g}(31.1 \%)$, n-hexane by $28.8 \mathrm{~g}(21.5 \%)$, and ethyl acetate by $37 \mathrm{~g}(27.7 \%)$. This solvent has the ability to separate the compounds in the extract based on their polarity.

\section{Thin Layer Chromatography Test (TLC)}

Table 2.

White turmeric Phytochemical Test Results.

\begin{tabular}{lll}
\hline Test Material & Color Spotting & Compound Group \\
\hline Extract & Purple & Steroids / Terpernoid (Essential Oil) \\
& Dark yellow & Alcholoid \\
& Yellow & Flavonoids \\
\hline N-Hexane fraction & Purple & Steroids / Terpernoid (Essential Oil) \\
\hline Ethyl Acetate Fraction & Dark yellow & Alcholoid \\
\hline Methanol Water & Yellow & Flavonoids \\
\hline
\end{tabular}

In determining the group of compounds contained in the extract and fraction of the white turmeric is by using the thin layer chromatography method (TLC) of GF245 silica gel plate size of $1 \mathrm{~cm} \mathrm{x} 7 \mathrm{~cm}$, then developed with the appropriate eluent/mobile phase, and leave it. The end of the GF245 selica gel plate was then removed and left dry. The GF245 silica gel 
plate was then sprayed with $1 \% \mathrm{H} 2 \mathrm{SO} 4$ and placed on the hot plate to observe the spots appearred.

Based on the results of the phytochemical test, it showed that in the extract and fraction of white turmeric, there were components of steroids/terpenoids, essential oils, alkaloids, and flavonoids. The phytochemical test is in line with the phytochemical test. According to (Murwati and Nurrahmat, 2000), white turmeric is included in the Zingiberaceae family. It contains chemicals in the form of $1-1.5 \%$ essential oil, curcumin, gum, resin, starch, and tannins. Other compounds are also found in white turmeric, such as saponins, flavonoids, and polyphenols. Hartono's research (2011) found that the essential oil produced by Curcuma zedoaria has a distinctive smell of essential oils. The resulting oil is purple, so at first glance it will appear black. In addition, the chemical content contained in the white turmeric are curcumin, zedoarin, gum, resin, starch, saponins, flavonoids, polyphenols, and zingiberene.

\section{Weight Homogeneity Test of White Male Rats}

Result of homogeneity test of white male rats (Rattus norvegicus) can be seen in the table below:

Table 3.

Result of Homogeneity Test of Male White Rats after Giving White turmeric extract and fraction

\begin{tabular}{llll}
\hline Group & Type of Treatment & $\begin{array}{c}\text { Rat body weight } \\
\text { (grams) } \\
\overline{\mathbf{x}} \pm \mathrm{SD}\end{array}$ & $p$ value \\
\hline $\mathrm{K} 0$ & CMC $1 \% 2 \mathrm{ml}$ & $212.00 \pm 10.954$ \\
\hline $\mathrm{P} 1$ & Extract $300 \mathrm{mg} / \mathrm{kgBW}$ & $216.00 \pm 6.519$ \\
\hline $\mathrm{P} 2$ & N-Hexane fraction $300 \mathrm{mg} / \mathrm{kgBW}$ & $213.00 \pm 4.472$ & \\
\hline $\mathrm{P} 3$ & Ethyl Acetate Fraction $300 \mathrm{mg} / \mathrm{kgBW}$ & $220.00 \pm 6.124$ \\
\hline $\mathrm{P} 4$ & Methanol Fraction Water $300 \mathrm{mg} / \mathrm{kgBW}$ & $218.00 \pm 8.367$ \\
\hline
\end{tabular}

Levene test $p=0.05$

From Table 3, it can be seen that the average body weight of the rats on K1 was $212.00 \pm$ 10.954 , the body weight of the rats P1 was $216.00 \pm 6.519$, the body weight of rats P2 was $213.00 \pm 4.472$, the body weight of rats P3 was $220.00 \pm 6.124$, and the body weight of rats $\mathrm{P} 4$ was $218.00 \pm 8.367$. From the results of the homogeneity test, the value obtained was $p=$ 0.448 ( $>>0.05$ ) which means that the body weight of the rats in each treatment was homogeneous.

Effect of Giving Extracts and Fraction of White Turmeric to Epididymis weight.

Through the provision of extract and fraction of white turmeric [C. zedoaria (Berg.) Roscoe] for 48 days showed a decrease in mean epididymal weight. As for seeing the decrease in the average, an analysis was carried out using the One Way Anova test and continued with Duncan's continued test to see the difference in the mean epididymal weight between each treatment group with a value of $\alpha 5 \%(0.05)$, while the results of the analysis can be seen in Table 4. 
Table 4.

The Average Test Results on the Effect of White Turmeric Extract and Fraction on Epididymal Weight.

\begin{tabular}{|c|c|c|c|}
\hline Group & Type of Treatment & $\begin{array}{l}\text { epididymal weight } \\
\overline{\mathbf{x}} \pm \mathrm{SD}\end{array}$ & p value \\
\hline K0 & CMC $1 \% 2 \mathrm{ml}$ & $0.480 \pm 0.019 \mathrm{a}$ & \multirow{5}{*}{0.001} \\
\hline $\mathrm{P} 1$ & Extract $300 \mathrm{mg} / \mathrm{kgBW}$ & $0.454 \pm 0.0125 \mathrm{~b}$ & \\
\hline $\mathrm{P} 2$ & N-Hexane fraction $300 \mathrm{mg} / \mathrm{kgBW}$ & $0.426 \pm 0.0152 \mathrm{c}$ & \\
\hline P3 & Ethyl Acetate Fraction $300 \mathrm{mg} / \mathrm{kgBW}$ & $0.411 \pm 0.217 \mathrm{~cd}$ & \\
\hline $\mathrm{P} 4$ & Methanol Fraction Water $300 \mathrm{mg} / \mathrm{kgBW}$ & $0.397 \pm 0.0176 \mathrm{~d}$ & \\
\hline
\end{tabular}

One Way ANova $\mathrm{p}<0.05$

Table 4 shows that the epididymal weight of white male rats (Rattus norvegicus) after the ANOVA test was $p$ value $=0.001(\mathrm{p}<0.05)$. This indicates that there was a difference in the mean between treatment groups from the provision of the white turmeric fraction. The results of further analysis with the Multiple Comparisons (Posthoc Test) Duncan Test showed that there was a decrease in epididymal weight of white male rated. The decrease began to look different in the K0 group compared to the P1, P2, P3, and P4 groups. There was a significant difference. In the P1 group compared to P2, P3, and P4 which were significantly different. P2, $\mathrm{P} 3$, and $\mathrm{P} 4$ groups had the same effectiveness but in the P4 treatment group can reduce the epididymal weight of the white male rats more.

The homogeneity test results of body weight of white male rats from each group of extracts and fractions influenced the epididymal weight. In the fraction group, it was seen that the water methanol fraction from white turmeric had greater influence on epididymal weight. The decrease in epididymal weight when depicted in the form of a histogram image as follows.

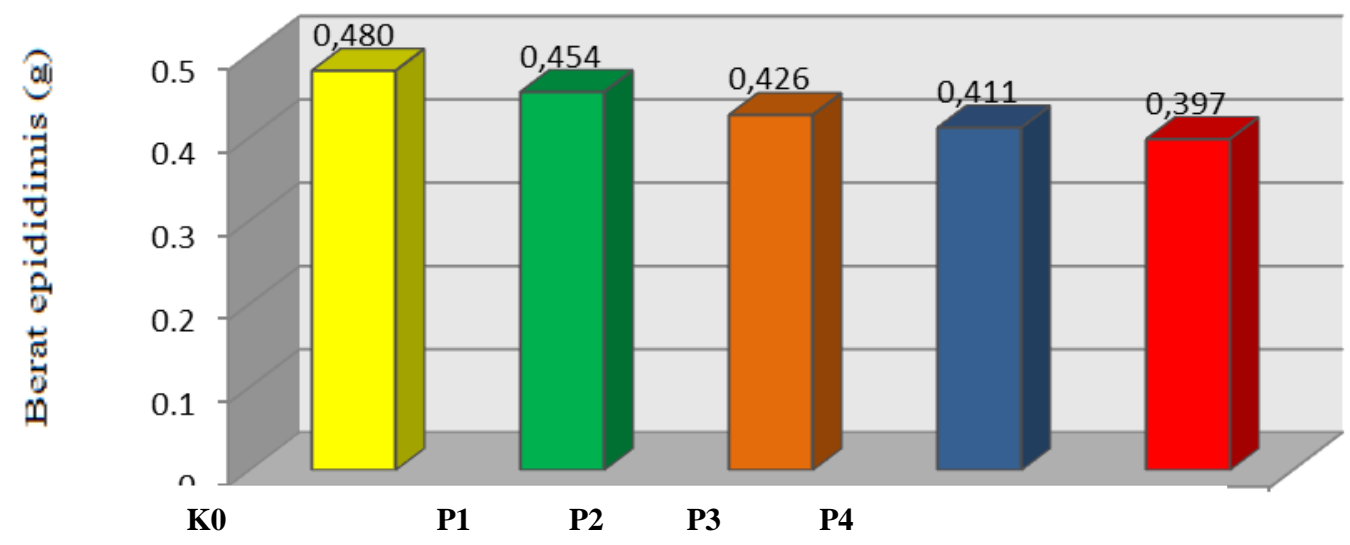

Picture 1. Histogram of the Mean Epididymal Weight in each group.

\section{The Effect of Giving White Turmeric Extract and Fraction on Epithelial Thickness in Epididymal Caput.}

The effect of giving the extract and fraction of white turmeric for 48 days showed a decrease in the mean thickness of the epithelium on the head of the epididymis. To see the decrease in the average thickness of the epithelium, an analysis was carried out using the One Way Anova test and continued with Duncan's test to see the difference in the mean thickness of the caput epithelium in each treatment group, while the results of the analysis can be seen in Table 5. 
Table 5.

The Average Test Results on the Effect of Extracts and Fractions of White Turmeric on Epithelial Thickness in Headache Epididymis.

\begin{tabular}{llll}
\hline Group & Type of Treatment & $\begin{array}{l}\text { Caput Epithelial } \\
\text { Thickness } \\
\overline{\mathbf{x}} \pm \mathrm{SD}\end{array}$ & p value \\
& & $50.778 \pm 5.658 \mathrm{a}$ \\
\hline $\mathrm{K} 0$ & CMC $1 \% 2 \mathrm{ml}$ & $41.142 \pm 6.285 \mathrm{~b}$ \\
\hline P1 & Extract $300 \mathrm{mg} / \mathrm{kgBW}$ & $30.224 \pm 12.347 \mathrm{c}$ & \\
\hline P2 & N-Hexane fraction $300 \mathrm{mg} / \mathrm{kgBW}$ & $23.686 \pm 4.732 \mathrm{c}$ \\
\hline P3 & Ethyl Acetate Fraction $300 \mathrm{mg} / \mathrm{kgBW}$ & \\
\hline P4 & Methanol Fraction Water $300 \mathrm{mg} / \mathrm{kgBW}$ & $20.792 \pm 3.668 \mathrm{c}$ \\
\hline
\end{tabular}

Note: The numbers followed by different letters showed that there was a significant difference in the Duncan advanced test $(\mathrm{p}<0.05)$.

From Table 5, it can be seen that the thickness of the caput epithelium after the ANOVA test obtained $p$ value $=0.001(\mathrm{p}<0.05)$. This indicates that there was a difference in the mean between the treatment groups from the provision of white turmeric fraction. The results of further analysis with the Multiple Comparisons (Posthoc Test) Duncan Test showed that there was a decrease in the thickness of the caput epithelium, the decrease began to look different in the K0 group compared to the P1, P2, P3, and P4 groups which showed a significant difference. In the P1 group compared to P2, P3, P4 were significantly different.

Groups P2, P3, and P4 have the same effectiveness but in the treatment group P4 can reduce the thickness of the head epithelium more.

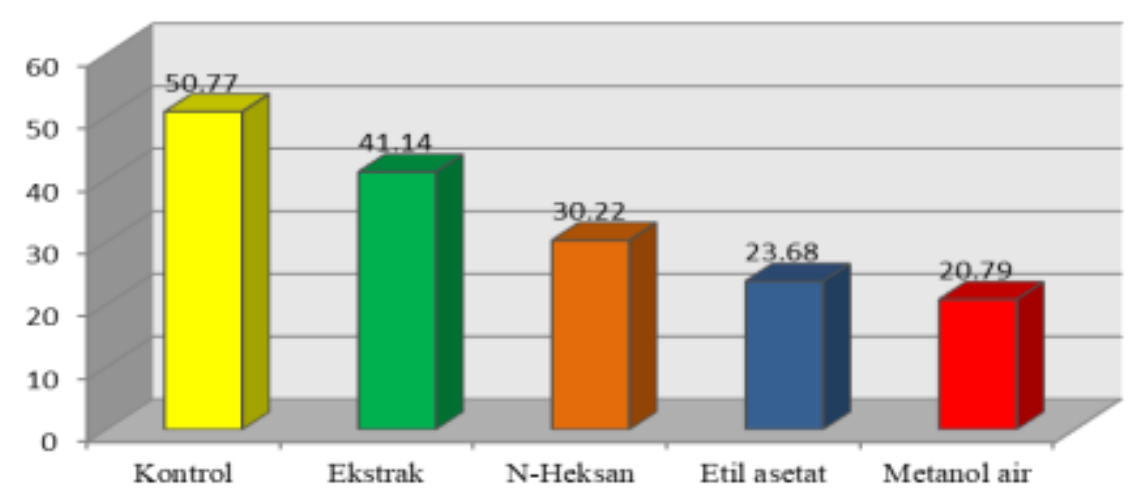

Figure 2. Histogram of Caput Epithelial Thickness in each group

The average test results of the effect of epithelial thickness on the epididymal head of male white rats from each group of extracts and fractions affected the thickness of the epithelial head of the epididymis but in the fraction group it influenced the thickness of the caput epithelium more. The decrease of the head epithelial thickness when depicted in the form of a histogram image as follows.

From the average effect of epithelial thickness on the epididymal head of white male rats, it was known that from each group the fraction that had more influences on the thickness of the epithelium in the head of the epididymis was the water methanol fraction of white rats, so it was known that the fraction that had more influences the decrease in the thickness of the epithelium in the head of the epididymis is known by giving water methanol fraction at a dose of $300 \mathrm{mg} / \mathrm{kgBW} /$ day orally with an orogastric cannula. Therefore, it is concluded that the 
provision of water methanol fraction can affect the thickness of the caput epithelium, which causes the thickness of the epididymal caput epithelium to decrease.

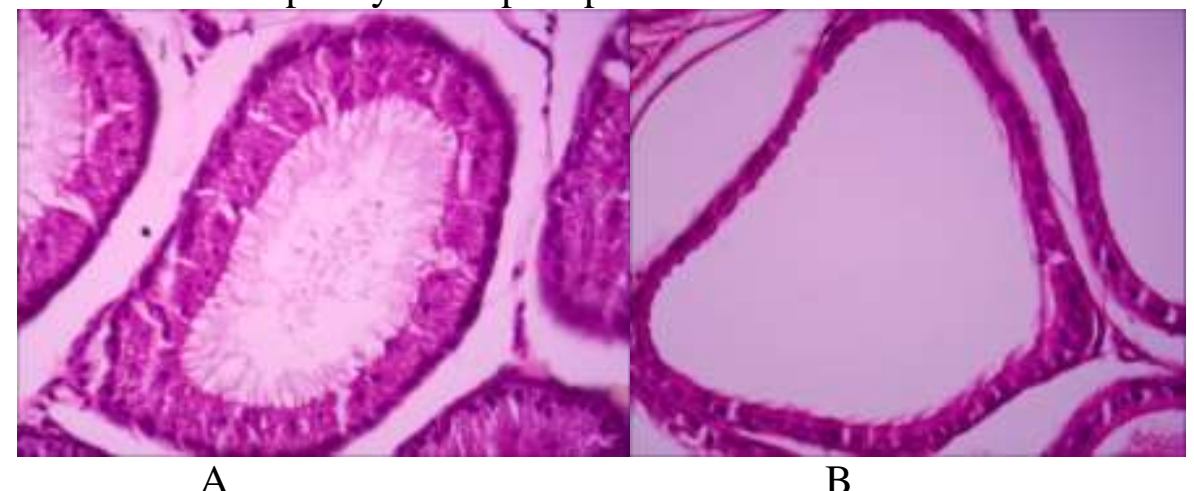

Figure 3.The histology of the head of the epididymis of male white rats with a cross section using 400x magnification. (A). Head epithelial thickness in (K0) control group, (B). The thickness of the caput epithelium in (P4) the water methanol treatment group of white turmeric.

Effect of Giving Extracts and Fraction of White Turmeric to Epithelial Thickness in the Corpus Epididymis.

The effect of giving extract and fraction of white turmeric (C. zedoaria (Berg.) Roscoe) for 48 days showed a decrease in mean epithelial thickness in the corpus. As for seeing the decrease in the average thickness of the epithelium, an analysis was carried out using the One Way Anova test and continued with Duncan's test to see the difference in the mean thickness of the corpus epithelium in each treatment group, the results of the analysis can be seen in Table 6 .

Table 6.

Average Test Results Effect of White Turmeric Extract and Fraction on Epithelial Thickness in Corpus Epididymis

\begin{tabular}{|c|c|c|c|}
\hline Group & Type of Treatment & $\begin{array}{l}\text { Corpus Epithelium } \\
\text { Thickness } \\
\overline{\mathbf{x}} \pm \text { SD }\end{array}$ & p value \\
\hline K0 & CMC $1 \% 2 \mathrm{ml}$ & $48.926 \pm 2.882 \mathrm{a}$ & \multirow{5}{*}{0.001} \\
\hline P1 & Extract $300 \mathrm{mg} / \mathrm{kgBW}$ & $37.579 \pm 6.483 b$ & \\
\hline $\mathrm{P} 2$ & N-Hexane fraction $300 \mathrm{mg} / \mathrm{kgBW}$ & $24.211 \pm 11.995 \mathrm{c}$ & \\
\hline P3 & Ethyl Acetate Fraction $300 \mathrm{mg} / \mathrm{kgBW}$ & $23.162 \pm 10.209 \mathrm{c}$ & \\
\hline $\mathrm{P} 4$ & Methanol Fraction Water $300 \mathrm{mg} / \mathrm{kgBW}$ & $20.732 \pm 4.521 \mathrm{c}$ & \\
\hline
\end{tabular}

Note: The numbers followed by different letters showed that there was a significant difference in the Duncan advanced test $(\mathrm{p}<0.05)$.

From Table 6 above, it can be seen that the thickness of the corpus epithelium after the ANOVA test is carried out, obtained $p$ value $=0.001(\mathrm{p}<0.05)$. This indicates that there was a difference in the mean between the treatment groups from the provision of white turmeric fraction. The results of further analysis with the Multiple Comparisons (Posthoc Test) Duncan Test showed that there was a decrease in the thickness of the corpus epithelium, the decrease began to look different in the K0 group compared to the P1, P2, P3, and P4 groups which showed a significant difference. The P1 group compared to P2, P3, and P4 were significantly different. Furthermore, groups P2, P3, and P4 had the same effectiveness but in the treatment group $\mathrm{P} 4$ can reduce the thickness of the corpus epithelium more. 
The average test results on the effect of epithelial thickness on the corpus epididymis of white male rats from each group of extracts and fractions affect the thickness of the epithelial head of the epididymis but in the fraction group it affects the thickness of the corpus epithelium more. The decrease of the thickness of the corpus epithelium is depicted in the form of a histogram image as follows.

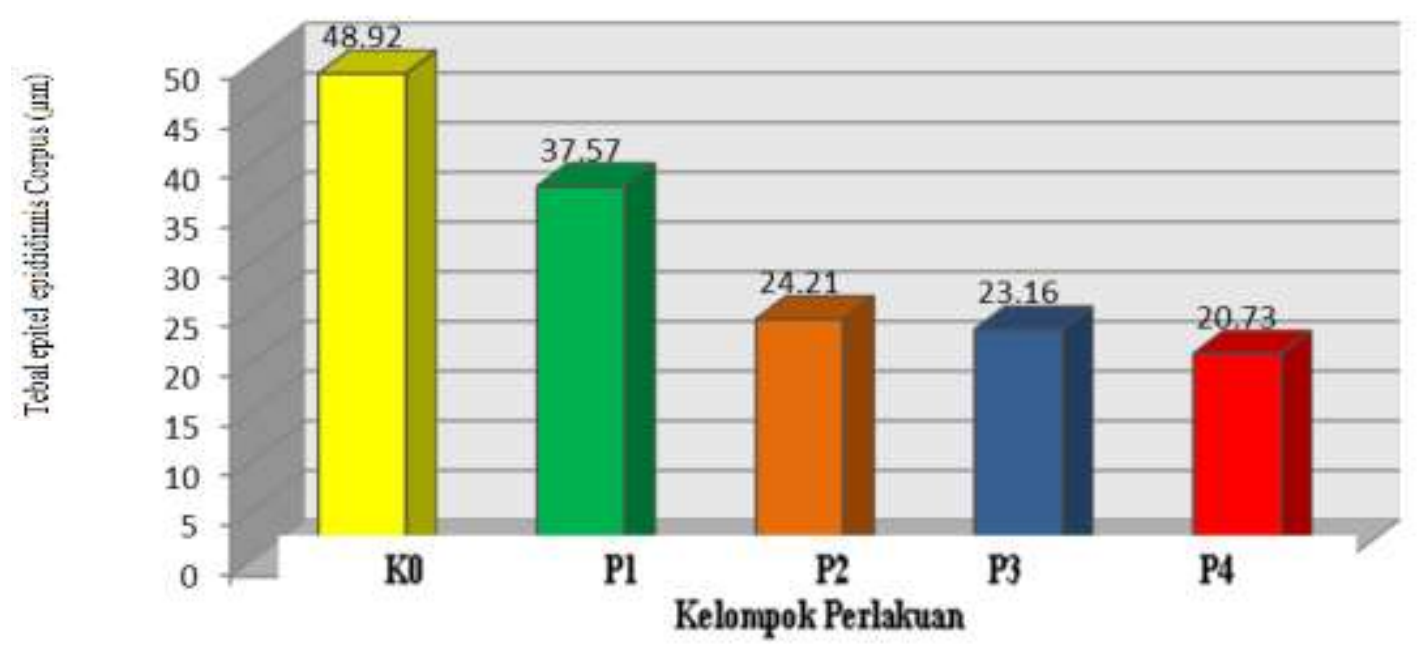

Figure 4. Histogram of Corpus Epithelial Thickness in each group

It is known that from each group the fraction affecting the thickness of the corpus epithelium was the water methanol fraction from white turmeric. So it can be concluded that from the provision of water methanol fraction of $300 \mathrm{mg} / \mathrm{kgBW} /$ day orally with orogastric cannula can affect the thickness of the epithelium. So it is concluded that the provision of water methanol fraction containing flavonoid compounds can affect the thickness of the corpus epithelium, which results in decreased thickness of the corpus epididymal epithelium.

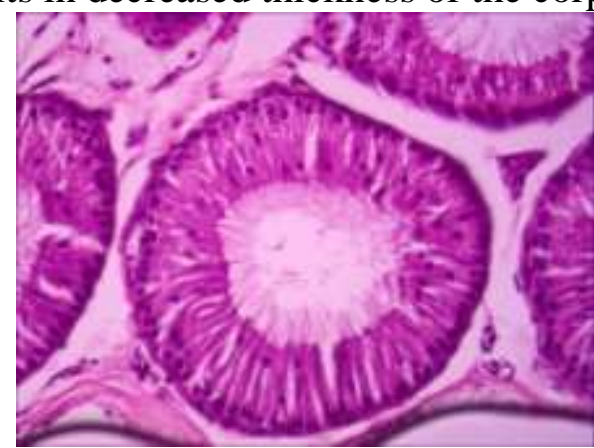

A

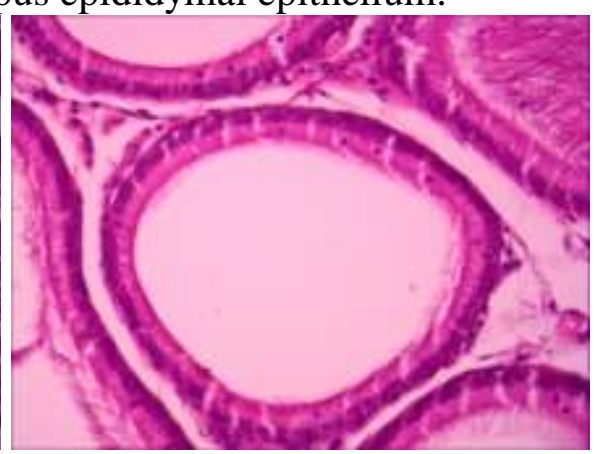

B

Figure 5.Histology of the corpus epididymis of white male rats with a cross section using 400x magnification. (A). Thick corpus epithelium in (K0) control group, (B). The thickness of the corpus epithelium in $(\mathrm{P} 4)$ the water methanol treatment group of white turmeric.

\section{Effect of Giving White turmeric Extract and Fraction on Epithelial Thickness in Cauda Epididymis.}

The effect of giving the extract and fraction of white turmeric for 48 days showed a decrease in the mean epithelial thickness in cauda. To see the average reduction in epithelial thickness, an analysis was performed using One Way Anova test and continued with Duncan's advanced test to see the difference in the mean cauda epithelial thickness in each treatment group, while the results of the analysis can be seen in Table 7. 
Table 7.

Average Test Results Effect of bzWhite turmeric Extract and Fraction on Epithelial Thickness in Cauda Epididymis

\begin{tabular}{|c|c|c|c|}
\hline Group & Type of Treatment & $\begin{array}{l}\text { Cauda Epithelium } \\
\text { Thickness } \\
\overline{\mathbf{x}} \pm \text { SD }\end{array}$ & $p$ value \\
\hline K0 & CMC $1 \% 2 \mathrm{ml}$ & $51.382 \pm 2.797 \mathrm{a}$ & \multirow{5}{*}{0.001} \\
\hline P1 & Extract $300 \mathrm{mg} / \mathrm{kgBW}$ & $46.573 \pm 3.016 \mathrm{~b}$ & \\
\hline $\mathrm{P} 2$ & $\mathrm{~N}-\mathrm{Hexane}$ fraction $300 \mathrm{mg} / \mathrm{kgBW}$ & $18.594 \pm 1.718 \mathrm{c}$ & \\
\hline P3 & Ethyl Acetate Fraction $300 \mathrm{mg} / \mathrm{kgBW}$ & $20.877 \pm 2.301 \mathrm{c}$ & \\
\hline $\mathrm{P} 4$ & Methanol Fraction Water $300 \mathrm{mg} / \mathrm{kgBW}$ & $19.813 \pm 2.440 \mathrm{c}$ & \\
\hline
\end{tabular}

Note: The numbers followed by different letters showed that there was a significant difference in the Duncan follow-up test $(\mathrm{p}<0.05)$.

From Table 7, it can be seen that the thickness of the cauda epithelium after the ANOVA test was carried out, obtained $p$ value $=0.001(\mathrm{p}<0.05)$. This indicates that there was a difference in the mean between treatment groups from the provision of the white turmeric fraction. The results of further analysis with the Multiple Comparisons (Posthoc Test) Duncan Test which showed that the decrease in cauda epithelial thickness began to look different in the K0 group compared to the P1, P2, P3, and P4 groups which showed a significant difference. The P1 group compared to P2, P3, and P4 were significantly different. For P2, P3, and P4 groups have the same effectiveness but in $\mathrm{P} 2$ treatment group can reduce cauda epithelial thickness more.

The average test results of the effect of epithelial thickness on the cauda epididymis of male white rats from each group of extracts and fractions affect the thickness of the cauda epididymal epithelium but in the fraction group it affects the thickness of the cauda epithelium more, seen in the n-hexane fraction of white turmeric containing steroid compounds/terpenoids (essential oils) have a greater effect on the decrease in thickness of the cauda epithelium when depicted in the form of a histogram image as follows.

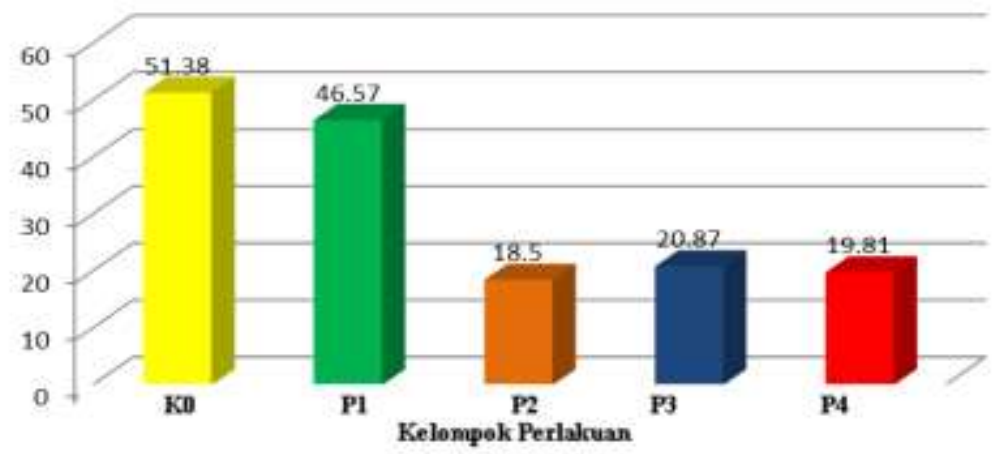

Figure 6. Cauda Epithelial Thickness Histogram in each group

From the results of the average effect of epithelial thickness on the cauda epididymis of white male rats, it can be seen that from each group the larger fraction that affects the thickness of the cauda epithelium is the n-hexane fraction of white turmeric containing flavonoids, it is known that the decrease in the testosterone hormone can cause changes in the ductus epididymis, namely degeneration of cauda epididymal epithelial cells, causing these epithelial cells to decrease. 


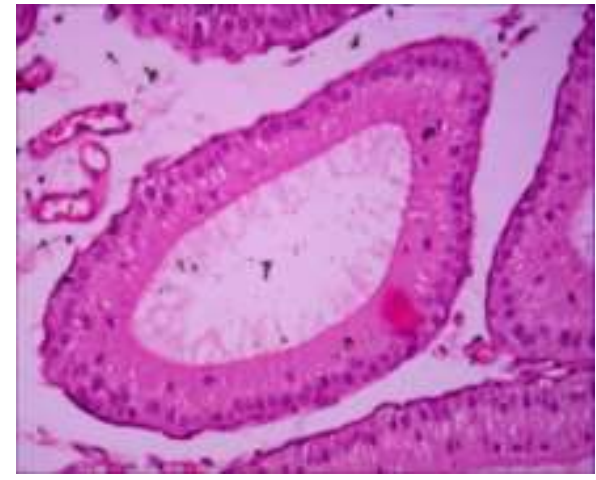

A

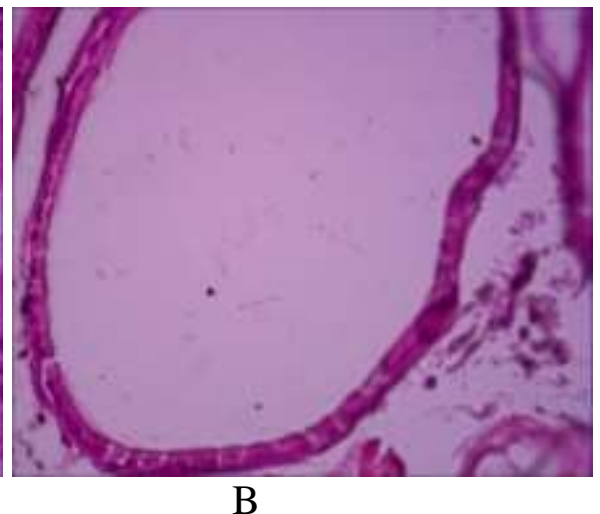

$\mathrm{B}$

Figure 7.Cauda epididymis histology of white male rats with cross section and using 400x magnification. (A). Cauda epithelial thickness in (K0) control group, (B). Cauda epithelial thickness in $(\mathrm{P} 4) \mathrm{n}$-hexane treatment group of white turmeric.

\section{DISCUSSION}

\section{Effect of Giving White turmeric Extract and Fraction on Epididymal Weight}

The results of the average effect of the epididymal weight of white male rats can be seen that from each group the fraction that affect the epididymal weight of white male rats more was the fraction of white turmeric. It is known that the fraction that affected the epididymal weight more was the lowest water methanol fraction at a dose of $300 \mathrm{mg} / \mathrm{kgBW} /$ day orally with an orogastric cannula, so it is concluded that the administration of the water methanol fraction can affect the epididymal weight, which results in epididymal weight to decrease. In addition, the water methanol fraction has flavonoid compounds that can cause mechanical damage to epithelial cells. This is in line with Delfita (2014) that the chemical content of flavonoids can lead to a decrease in epididymal weight. According to Ashok and Meenaksh (2004), giving turmeric extract (Curcuma longa L.) to white rats showed that the epididymal weight decreased, which was thought to be caused by the content of flavonoids in turmeric.

The decrease in epididymal weight is considered to be a disturbance in the development and function of the epididymis. According to Paz and Homonnai (1986), the reduction in epididymal weight is caused by the decrease in the testosterone hormone which controls the epididymal function. The decrease of testosterone hormone occurs because FSH decreases and LH is inhibited. Due to this decrease in the testosterone hormone, it causes changes in the epididymal duct, namely epididymal epithelial degeneration. In addition, the epididymis is a site for spermatozoa maturation. So that another possibility of the reduction in epididymal weight is considered to be caused by steroids that bind to estrogen receptors which can cause a decrease in testosterone and FSH levels which results in disruption of the spermatogenesis process and can even cause atrophy in spermatogenic cells (Cholifah et al., 2014)

In addition, the decrease in epididymal weight is another possibility caused by the water methanol fraction from white turmeric which has flavonoid compounds, which can disrupt the epididymal cell membranes so that it can also affect the secretion of the testosterone hormone which plays a role in maintaining the survival of spermatozoa in the epididymis (Ashok and Meenakshi, 2004). In addition, flavonoid compounds that have activity such as estrogen can also suppress the function of the anterior pituitary to secrete FSH and LH (Suartha, 2005). In addition, the epididymis is a site for spermatozoa maturation. So that another possibility of the reduction in epididymal weight is thought to be due to steroids that bind to testosterone receptors which can cause a decrease in testosterone and FSH levels which results in disruption of the spermatogenesis process and can even cause atrophy in spermatogenic cells 
(Taufiqurrahman, 1999). If the number of spermatozoa decreases, the weight of the epididymis will also decrease.

\section{The Effect of Giving White turmeric Extract and Fraction on Epithelial Thickness in Epididymal Caput.}

Based on the results of the study, giving fractions of white turmeric can reduce the thickness of the epithelial head of the epididymis. The shrinkage in the thickness of the epithelium is thought to be due to the presence of flavonoids, alkoloid compounds, steroids/terpenoids (essential oils) in White turmeric which can affect the testosterone hormone. This is in line with Ashfahani et al., (2000), who stated that giving white turmeric extract containing flavonoid compounds can disrupt the secretion of the testosterone hormone by leydig cells.

According to Robaire and Vinger (1995), testosterone regulates the morphology of epididymal epithelial cells, so that if the amount of testosterone decreases it will affect the thickness of the epididymal epithelium. Testoterone plays a role in regulating the morphology of epididymal epithelial cells. If testosterone decreases, the morphology of epididymal epithelial cells will decrease and if the longer there will be degeneration of epididymal epithelial cells. The decrease in the thickness of the epididymal caput epithelium is thought to be due to the flavonoid compounds contained in the white turmeric which can result in decreased FSH secretion and inhibited LH. Because LH secretion is inhibited, it causes the growth and number of leydig cells to decrease so that the secretion of the testosterone hormone is also reduced. This is because leydig cells are the site of the steroidogenesis process which produces testosterone. After being secreted, then the testosterone produced by the leydig cells is transported in high concentrations to the seminiferous tubules. Then, the testosterone that enters the seminiferous tubulus is bound by ABP produced by the Sertoly cells (Csherwood, 2001). Because FSH decreases, ABP synthesis also decreases, causing the transport of testosterone to the epididymis causing atrophy of epithelial cells.

The epididymis has a protective function and an immune function carried out by halo cells (Robaire and Viger, 1995). If the testosterone decreases, the function of the halo cells in the epididymis as defense will be disrupted as a result of which toxic bioactive materials such as: steroids/terpenoids, essential oils, alkaloids, and flavonoids can affect the thickness of the epididymal epithelium, resulting in degeneration of the epididymal epithelial cells which has an impact decreased thickness of the epididymal epithelium. Testosterone which regulates the morphology of epididymal epithelial cells. The decrease in the thickness of the epididymal head epithelium is $\mathrm{c}$ to be due to the flavonoids that bind to the estrogen receptor resulting in decreased FSH secretion and inhibited LH.

A decrease in the thickness of the epididymal epithelium can affect spermatozoa, which in turn Spermatozoa should undergo several maturation processes such as gaining the ability to move passively through the seminiferous tubule. According to Senger (1999), epididymis is a very important channel as a determinant of the fertility of the resulting sperm, because spermatozoa produced in the seminiferous tubules will be flowed into the epididymis through the head to undergo a maturation process before they have the ability to move (motile) and fertilize oocytes.

\section{Effect of Giving Extracts and Fraction of White turmeric to Epithelial Thickness in the Corpus Epididymis.}

There was a decrease in the thickness of the corpus epithelium between the control and treatment groups. The main function of the epididymal duct lies in the corpus which absorbs 
the fluid secreted by the testes. Thus, it is known that the thick corpus epithelium has a high absorption activity and the epididymal epithelium is responsible for absorption not only of the fluid secreted by the seminiferous tubules through the rete testis, but also ions and small organic molecules (Setchell, 1988). The thick shrinkage of the epididymal epithelium is thought to be caused by flavonoids, alkaloids, steroids/terpenoids (essential oils) which are present at White turmeric. Flavonoid compounds can reduce the testosterone hormone as a result, the function of the Sertoli cells which is affected by testosterone is disturbed. The disruption in the Sertoli cells causes the synthesis of androgen wall protein (ABP) to be disrupted. This ABP serves as a carrier to the epididymis. The decrease in ABP causes a decrease in testosterone which is required by the epididymis(Wahyuni et al., 2012)

According to Arsyad (1980), a decrease in the amount of testosterone affects the thickness of the epididymal epithelium. In addition, according to Robaire and Vinger (1995) testosterone plays a role in regulating the morphology of epididymal epithelial cells. If testosterone decreases, the morphology of epididymal epithelial cells will decrease and if it is longer there will be degeneration of epididymal epithelial cells. In addition, the epididymis has a protective function and an immune function carried out by halo cells.

The epididymis has a protective function and an immune function carried out by halo cells. both of these functions are also highly dependent on testosterone (Robaire, 1995). If testosterone decreases, the function of halo cells in the epididymis as a defense is increasingly ineffective, then the lack of the process of increasing the number of cells in the epididymal epithelium can cause degeneration of epididymal epithelial cells which results in a decrease in the thickness of the epididymal epithelium which decreases when compared to the control group.

Meanwhile, another possibility that causes epididymal epithelial shrinkage is due to damage to the epididymal cell membrane due to the content or excessive dose of flavonoids which act as anti-oxidants to form reactive oxygen species (ROS) and will damage the cell membrane so that the epididymal cells become damaged and the metabolic process does not. running as it should. According to (Delfita, 2014), that the chemical content of excess flavonoid compounds can cause damage to epididymal cell membranes.

\section{Effect of Giving White turmeric Extract and Fraction on Epithelial Thickness in Cauda Epididymis.}

From Figure 7, it can be seen that there was a decrease in the thickness of the corpus epithelium between the control and treatment groups. Epithelial thickness shrinkage of the epididymis is considered to be caused by $n$-hexane from white ginger containing steroid/terpenoid compounds. Steroids are able to stimulate the formation of estrogen in the body, thereby increasing estrogen levels, increasing estrogen levels will provide negative feedback to the anterior pituitary, not to release FSH and LH which cause reduced testosterone secretion by leydig cells (Mitayani, 2009).

Because LH secretion is inhibited, it causes the growth and number of leydig cells to decrease so that the secretion of the testosterone hormone is also reduced. This is because leydig cells are the site of the steroidogenesis process that produces testosterone, if the amount or function is reduced, the production will decrease. After the secretion of testosterone is then bound by ABP secreted by the Sertoli cells because testosterone decreases, the ABP synthesis also decreases, causing a decrease in testosterone keepididimis transport and causing atrophy of epithelial cells.(Cholifah et al., 2014). 
The cauda area has the widest duct diameter and lumen diameter. This is because the cauda area is the largest storage area for spermatozoa in the epididymis. About $75 \%$ of the total number of spermatozoa in the epididymis are in the cauda epididymis (Ashdown and Hafez, 1993). In addition, optimal conditions in cauda are needed for the survival of spermatozoa during storage, so that if the conditions in the thickness of the cauda epithelium are disturbed, the survival of spermatozoa in the cauda will also be disturbed.

The decrease in the thickness of the cauda epididymal epithelium is thought to be caused by a steroid/terpenoid compound (essential oil) from n-hexane which affects estrogen receptors, resulting in inhibited LH secretion and decreased FSH. Because LH secretion is inhibited, it causes the growth and number of leydig cells to decrease so that the secretion of the testosterone hormone is also reduced. This is because leydig cells are the site of the steroidogenesis process that produces testosterone, if the amount and function is reduced, the production will decrease, so the testosterone hormone produced is reduced (Hanum, 2010).

The decrease in the amount of testosterone affects the thickness of the epididymal epithelium. In addition, according to Robaire and Vinger (1995) testosterone plays a role in regulating the morphology of epididymal epithelial cells. If testosterone decreases, the morphology of epididymal epithelial cells will decrease and if the longer there will be degeneration of epididymal epithelial cells. Decreased levels of testosterone and FSH which result in disruption of the spermatogenesis process can even cause atrophy of spermatogenic cells (Taufiqurrahman, 1999 in) so that it can also cause the number of spermatozoa stored in the cauda epididymis to decrease.

According to Verma (2002), the function of the epididymis depends on the testosterone hormone, the decrease in testosterone levels can affect sperm maturation in the epididymis. A decrease in the number of sperm in the cauda epididymis is an indicator of a decrease in spermatogenesis due to the presence of toxicity agents found in white turmeric which contain steroids/terpenoids (essential oils) from n-hexane.

\section{CONCLUSION}

The administration of extract and fraction of white turmeric (C. zedoaria (Berg.) Roscoe) can influence changes in the weight and histology of the epididymis of white male rats (Rattus norvegicus).

\section{REFERENCES}

Arsyad, KM. (1980). Prociding Spermatogenesis Seminar. Board of the Andrology Association (PANDI) Surabaya.

Ashdown, RR and ESE Hafez. (1993). Anatomy of Male Reproduction. Itz ESE Hafez (ed): Reproduction in Farm Animals. 6 "ed. Lea \& Febiger. Philadelphia.pp: 3-19.

Ashok, P., B. Meenakshi. (2004). Contraceptive Effect Of Curcuma longa (L.) in Male Albino Rat. Available at:http: // www. Asian J Androl.com Opened: 23.10.2015

Ashfahani, ED, Wiratmini, NI Sukmaningsih. (2000). Motility and Viability of Mouse Spermatozoa (Musmusculus L.) After Giving White turmeric Extract (Curcuma Zedoaria (Berg.) Roscoe.). Journal of Biology XIV. ISSN 14105292.

Biology, J., \& Viability, ON (2010). Motility and Viability of Mice (Mus Musculus L.) 
Spermatozoa After Giving White turmeric Extract (Curcuma Zedoaria (Berg.) Roscoe.). Journal of Biology, 14 (1). https://doi.org/10.24843/jbiounud

Cholifah, S., Arsyad, \& Salni. (2014). The Effect of Giving Pare Extract (Momordica Charantia, L) on the Histological Structure of the Testes and Epididymis of Male Rats. Mks, 46 (2), 149-157.

Delfita, R. (2014). Antifertility Potential of Black Tea Extract in Male Mice (Mus musculus L.). Journal of Science and Technology of IAIN Batusangkar, 6 (2), 181-188.

Handajani, NS (2003). Cytostatic activity of White turmeric (Curcuma zedoaria (Berg.) Roscoe.) On the spermatogenic cells of Mice (Mus Musculus L.) BioSMART Journal 5 (2): $120-123$.

Hanum M, (2010). Reproductive Biology, Nuhamedika, Jogjakarta

Hartono Maiyani, Nurlaila, Batubara Irmanida (2011) Potential of White turmeric (Curcuma Zedoaria) as Anti-Bacterial and Chemical Compound Contents. Bogor Agricultural Institute 203-212

Martinez GM, Chandra A, Amba JC, Jones J, Mosher WD. Fertility, contraception, and fatherhood data on men and women from cycle 6 (2002) of the 2002 National Survey of Family Growth. Vital Health and Statistics; 2006: 2003: 1

Mitayani. (2009). The Effect of Pare (Momordica charantia L) Extract on the Number of Spermatozoa, Seminiferous Tubule Diameter and Testicular Weight of Wistar Male Rats as Natural Contraceptives. Unpad Thesis.

Naomi, B., \& Sari, R. (2016). Email: lppm.akjp2@gmail.com. 1 (1), 44-59.

Siswanti, T., Astirin, OP, \& Widiyani, T. (2003). Effect of White turmeric Extract (Curcuma zedoaria Rosc.) On Spermatogenesis and Quality of Mice (Mus musculus L.) Spermatozoa. 5 (April), 38-42.

Wahyuni, S., Agungpriyono, S., Agil, M., \& Yusuf, LT (2012). Histology and Histomorphometry of Testes and Peak Epididymis (Muntiacus muntjak muntjak) in Hard Antler Period. Veterinary, 13 (3), 211-219. 